\title{
Construction, purification, and characterization of a chimeric TH I antagonist
}

\author{
Iraldo Bello-Rivero*1, Yeny Torrez-Ruiz ${ }^{1}$, Elizabeth Blanco-Garcés ${ }^{1}$, \\ Giselle Pentón-Rol1, Osmani Fernández-Batista1, Luís Javier-González², \\ Haydee Gerónimo-Perez ${ }^{3}$ and Pedro López-Saura ${ }^{1}$
}

\author{
Address: ${ }^{1}$ Clinical Trial Department, Center for Biological Research, Calle 134 entre 23 y 25, Cubanacan, P.O. Box 6332, Havana, Cuba, \\ ${ }^{2}$ Physicochemical Division, Center for Genetic Engineering and Biotechnology, Calle 190 entre 31 y 33. Postal Code 10600, Havana, Cuba and \\ ${ }^{3}$ Department of Biologicals, Control Quality Division, Center for Genetic Engineering and Biotechnology, Calle 190 entre 31 y 33. Postal Code \\ 10600, Havana, Cuba \\ Email: Iraldo Bello-Rivero* - iraldo.bello@cigb.edu.cu; Yeny Torrez-Ruiz - yeny.torrez@cigb.edu.cu; Elizabeth Blanco- \\ Garcés - elizabeth.blanco@cigb.edu.cu; Giselle Pentón-Rol - giselle.penton@cigb.edu.cu; Osmani Fernández- \\ Batista - osmani.fernandez@cigb.edu.cu; Luís Javier-González - luis.javier@cigb.edu.cu; Haydee Gerónimo- \\ Perez - haydee.geronimo@cigb.edu.cu; Pedro López-Saura - lopez.saura@cigb.edu.cu \\ * Corresponding author
}

Published: 22 May 2006

BMC Biotechnology 2006, 6:25 doi:10.1 186/1472-6750-6-25

This article is available from: http://www.biomedcentral.com/1472-6750/6/25

(C) 2006 Bello-Rivero et al; licensee BioMed Central Ltd.

This is an Open Access article distributed under the terms of the Creative Commons Attribution License (http://creativecommons.org/licenses/by/2.0), which permits unrestricted use, distribution, and reproduction in any medium, provided the original work is properly cited.
Received: 18 October 2005

Accepted: 22 May 2006

\begin{abstract}
Background: $\mathrm{THI}$ immune response antagonism is a desirable approach to mitigate some autoimmune and inflammatory reactions during the course of several diseases where IL-2 and IFN$\gamma$ are two central players. Therefore, the neutralization of both cytokines could provide beneficial effects in patients suffering from autoimmune or inflammatory illnesses.

Results: A chimeric antagonist that can antagonize the action of THI immunity mediators, IFN- $\gamma$ and IL-2, was designed, engineered, expressed in $E$. coli, purified and evaluated for its in vitro biological activities. The THI antagonist molecule consists of the extracellular region for the human IFN $\gamma$ receptor chain I fused by a four-aminoacid linker peptide to human $60 \mathrm{~N}$-terminal aminoacid residues of IL-2. The corresponding gene fragments were isolated by RT-PCR and cloned in the PTPV-I vector. E. coli (W3 I I0 strain) was transformed with this vector. The chimeric protein was expressed at high level as inclusion bodies. The protein was partially purified by pelleting and washing. It was then solubilized with strong denaturant and finally refolded by gel filtration. In vitro biological activity of chimera was demonstrated by inhibition of IFN- $\gamma$-dependent HLA-DR expression in Colo 205 cells, inhibition of IFN- $\gamma$ antiproliferative effect on HEp-2 cells, and by a bidirectional effect in assays for IL-2 T-cell dependent proliferation: agonism in the absence versus inhibition in the presence of IL-2.
\end{abstract}

Conclusion: THI antagonist is a chimeric protein that inhibits the in vitro biological activities of human IFN- $\gamma$, and is a partial agonist/antagonist of human IL-2. With these attributes, the chimera has the potential to offer a new opportunity for the treatment of autoimmune and inflammatory diseases. 


\section{Background}

Interferon gamma (IFN- $\gamma$ ), produced by activated $\mathrm{T}$ and NK cells [1], macrophages and dendritic cells [2], has important immunomodulatory and inflammatory actions [3,4]. The activities of IFN- $\gamma$ are initiated following association of the cytokine with a membrane-bound receptor (IFNGR) present on many cell types [5]. The receptor comprises two subunits (IFNGR1 and IFNGR2). IFNGR1 has an extracellular portion of 228 residues [6], that also occurs in soluble form and can function as an endogenous IFN- $\gamma$ inhibitor [7]. Several pathological effects have been ascribed to IFN- $\gamma$ in animal models and in humans. IFN- $\gamma$ neutralization inhibits the lethal effect of endotoxin in an animal model of septic shock [8], as well as the rejection of tumor, skin, and heart allografts $[9,10]$. IFN- $\gamma$-mediates pancreatic beta-cell death and the subsequent development of immune-mediated diabetes $[11,12]$ and accelerates the development of lupus-like disease and nephritis in NZW $\times$ NZB- after treatment of F1 mice, whereas antibodies to IFN- $\gamma$ can block or delay the progression of the disease $[13,14]$. Additionally, administration of IFN- $\gamma$ can promote the development of reactive gliosis in the central nervous system (CNS) of adult mice [15] and aggravate the course of multiple sclerosis in humans [16]. These observations suggest that IFN- $\gamma$ antagonist may have therapeutic application in autoimmune diseases, chronic inflammation, and allograft rejection. Recently, an anti-IFN $\gamma$ antibody (Fontolizumab) has been demonstrated to be of a clinical benefit in patients suffering from Crohn's disease [17].

Interleukin 2 (IL-2) is a lymphokine synthesized and secreted primarily by T-helper lymphocytes that have been activated by stimulation with certain mitogens or by interaction of the T-cell receptor complex with an antigen/ MHC complex on the surfaces of antigen-presenting cells [18]. The biological activities of IL-2 are mediated through its binding to a multisubunit cellular receptor. Although three distinct transmembrane glycoprotein subunits contribute to the formation of the "definitive" high affinity IL2 receptor, various combinations of receptor subunits are known to occur $[19,20]$. Resting cells do not express highaffinity IL-2R, but activation with antigen rapidly [21] induces expression.

The main non-redundant activity of IL-2 consists in the regulation of T-cell tolerance [22] and along with IFN- $\gamma$ and TNF- $\beta$, it is a defining product of the TH1 subset. Production of IL-2 may contribute to the pathogenesis of some diseases: overproduction of IL-2 has been seen in patients with multiple sclerosis [23-25], systemic lupus erythematosus relapses [26], myasthenia gravis [27] and psoriasis [28]. However, recent studies indicate that failure of CD4 (+) CD25 (+) regulatory T cells to develop is the underlying cause of autoimmunity in the absence of
IL-2 [22]. These observations indicating that both IFN- $\gamma$ and IL-2 can promote pathogenesis of inflammation, prompted us to develop a chimeric protein TH1 antagonist that can simultaneously modulate the biological activities of both cytokines.

\section{Results and discussion Construction and expression of THI antagonist}

The poly-A mRNA for each nucleic acid to be cloned was amplified from Jurkat and Raji cells expressing IL-2 and high levels of IFNGR1, respectively. cDNAs for hu IL-2 Nterminal fragment (coding for the first 60 aminoacid residues) and IFNGR1 subunit extracellular region (coding for 228 amino acids) were isolated by RT-PCR amplification of isolated poly-A mRNA. The cloning strategy included amplification of each cDNA fragment using primers with overlapping nucleotides to permit fusion of the two bands in a later second round-PCR. The fragments were joined in a second PCR using the 5' primer from IL2 fragment amplification and the 3' primer for IFNGR1 extracellular fragment first-round amplification.

These primers contain the sequences suited for Nco I and Bam HI restriction enzyme cuts, compatible with respective restriction sites in the PTPV-1 expression vector, in which the final fused cDNA was inserted. The resulting vector contains a BamHI site just before the translational stop codon and the cloned fragment is denoted $\mathrm{pHu}$ (AnTH1). Figure 1 summarizes the strategy followed to obtain the expression vector $\mathrm{pHu}$ (AnTH1).

\section{Expression and purification of AnTHI}

W3110 P3 E. coli cells were transformed with pHu (AnTH1) plasmid incubated in $500 \mathrm{~mL}$ growth medium yielded about $1 \mathrm{~g}$ of $E$. coli wet biomass, in which TH1 antagonist protein constituted about $30 \%$ of the total protein (Figure 2A). A small quantity of TH1 antagonist was expressed at the start of the induction period, likely related to the fact that pTrip is a strong promoter difficult to be completely silenced. In the same figure, the lanes corresponding to the negative control show a band much fainter with the same migration rate as that of the recombinant molecule. This band was not observed after purification steps and therefore probably represents a comigrating E. coli protein.

Since expression in E. coli culture resulted in accumulation of the recombinant protein in insoluble "inclusion bodies", purification of expressed chimera was performed by washing the pellets using a low urea concentration, followed by a high urea concentration for the extraction (solubilization) processes. Comparative studies showed that $8 \mathrm{~mol} / \mathrm{L}$ urea solubilized approximately the 78\% of recombinant protein (see Table 1); lower concentrations of urea were less efficient (Figure. 2B and 2C) and were 


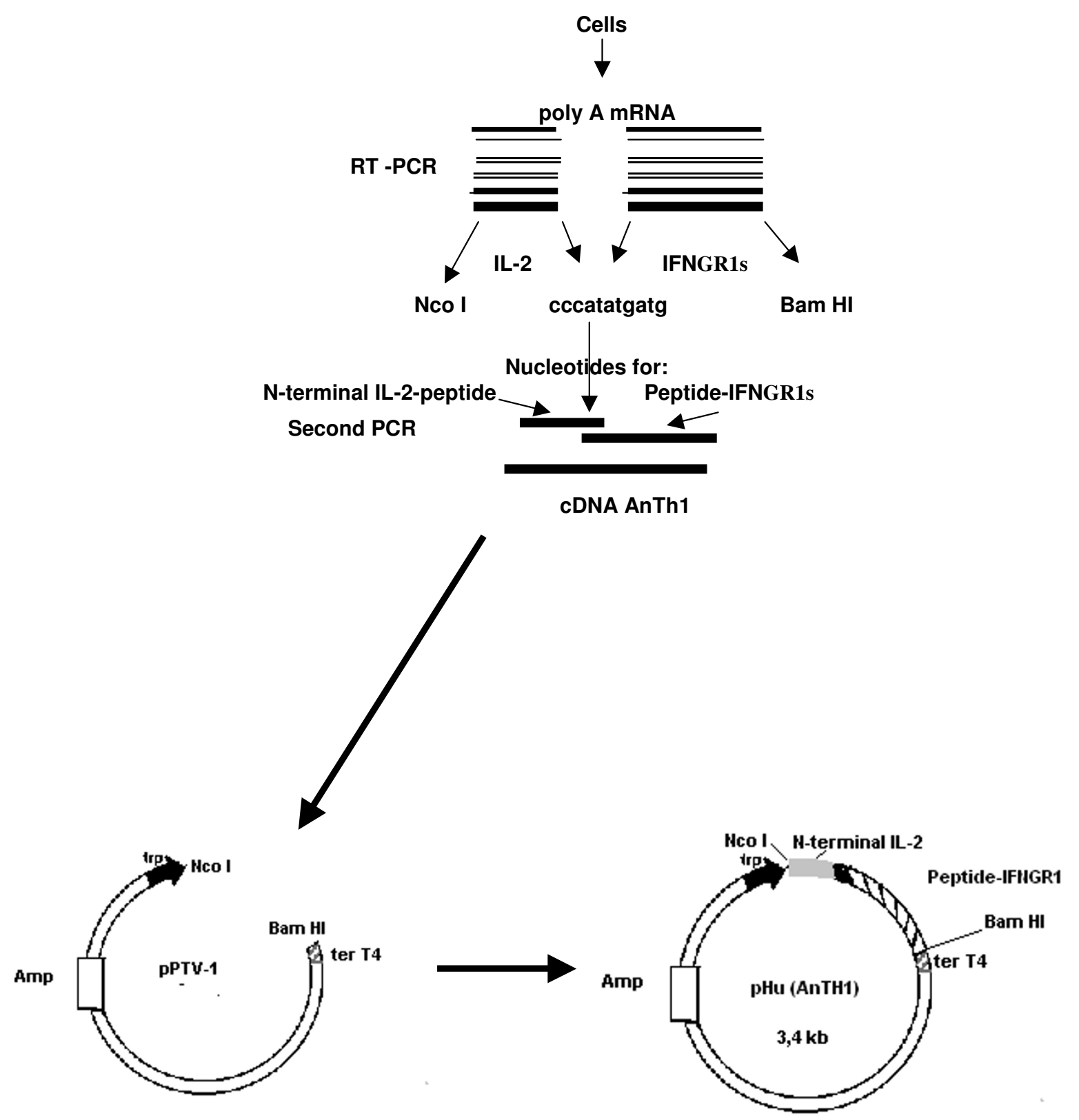

\section{Figure I}

Construction of the expression plasmid pHu (AnTHI). The figure illustrates the process started from Poly-A mRNA purification from cell lines, followed by the RT-PCR of respective cDNA fragments. The amplified cDNA THI antagonist (AnThI) contains in its extremes the sequences for $\mathrm{Ncol}$ and BamHI restriction enzymes suited for cloning in the pPTV-I vector (left at the bottom of diagram). In the center is indicated the nucleotide sequence (ccatatgatg) coding for the linking peptide. The final genetic construction is shown at the bottom right.

used for the washing steps. This approach achieves a good performance; since in the washed pellet the insoluble recombinant protein is retained while soluble E. coli proteins are washed out, providing a high grade of purification at the end of the process.
During the refolding process, realized by moving to a mild denaturating agent and finally to a physiological buffer, the reduced denatured protein recovers its active conformation, as demonstrated by protein ligand blots, where the active soluble chimera specifically bound radiolabed hu recombinant IFN- $\gamma$ (Figure 3), as well as by biological 
A

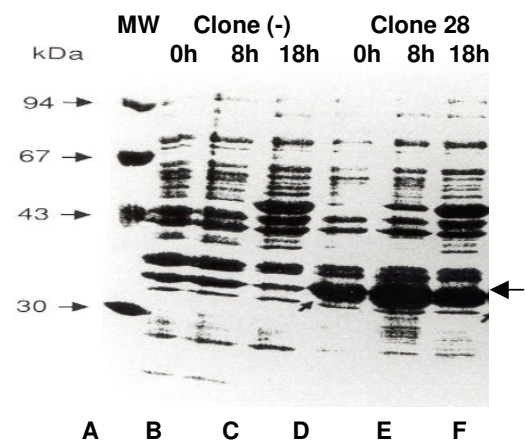

B

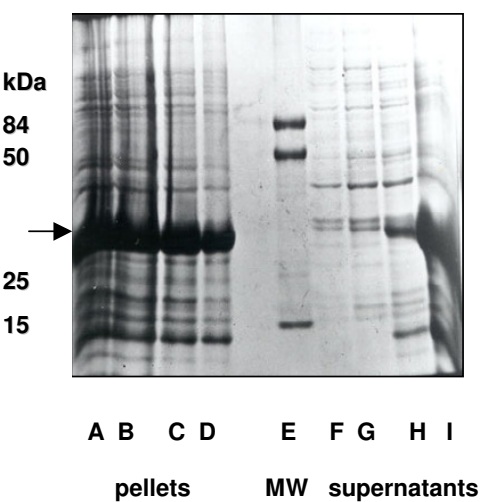

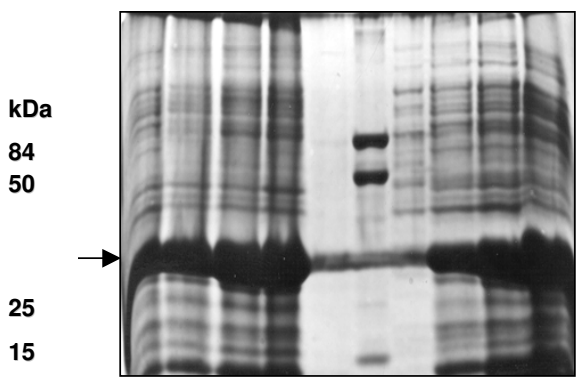

A B C D E $\quad F \quad G \quad H \quad$ MW supernatants

Figure 2

$E$ coli expression and urea extraction of recombinant chimeric protein. Panel A: Coomasie staining of I2.5\% SDSPAGE in reduced conditions of samples from $E$ coli expression. Lanes $A, B, C: E$ coli strain negative control (empty vector), 0,8 and 18 hours of induction; Lanes $D, E, F$ : E. coli strains containing the expression plasmid pHu (AnTHI) under induction conditions: 0, 8, and 18 hours of induction. Panel B: Urea extraction. Coomasie staining of $12.5 \%$ SDS-PAGE under reducing conditions. Lanes $A, B, C$, and $D$, pellets and lanes $F, G, H$, I, supernatants from extraction with $0,2,4$ and $8 \mathrm{~mol} / L$ urea. Panel $C$ : Lanes $A, B, C$, and $D$, pellets and lanes $F, G, H, I$, supernatants from extraction with $0,5,6$ and $7 \mathrm{~mol} / L$ urea. Lanes $E$ in panels $B$ and $C$ indicate the position of MW. The samples contain approximately the same amount of protein. The arrows indicate the position of AnThI recombinant protein

activity tests (see the next section). The main recombinant product is a $33 \mathrm{kDa}$ or $37 \mathrm{kDa}$ protein in non-reduced or reduced conditions, respectively, as recognized by anti-IL2 polyclonal antibody (Figure 4A). Shift in mobility of TH1 antagonist between non-reducing and reduced eletrophoretic conditions is in correspondence with what has been reported for the soluble IFNGR [29] and for several other receptors $[30,31]$ and is consistent with a more compact structure of folded protein. Polymeric and monomeric forms were detected, probably as a consequence of various alternative possibilities in the formation of disulfide bonds among the nine sulphydryl groups of the protein [32]. The anti-IL-2 polyclonal antibody strongly recognized the rhu IL-2 in Western blots, while the chimera was recognized less intensely, likely due to the small IL-2 fragment represented in the recombinant antagonist (see Figure 4B).

\section{Mass spectrometric analysis}

The tryptic peptides ESI-MS spectrum of TH1 antagonist was obtained with a very good agreement between the molecular masses of the predicted proteolytic fragments and the experimental values. A summary of this comparison is shown in Table 2 . Three tryptic peptides containing

Table I: Balance of several processes of AnTHI solubilization

\begin{tabular}{|c|c|c|c|c|c|c|}
\hline \multirow[b]{2}{*}{ Process Step } & \multicolumn{3}{|c|}{ Total protein $(\mathrm{mg})$} & \multicolumn{3}{|c|}{$\%$ of solubilization } \\
\hline & $\operatorname{Exp} \# 1$ & $\operatorname{Exp} \# 2$ & Exp \#3 & Exp \#I & $\operatorname{Exp} \# 2$ & Exp \#3 \\
\hline Supernatant $4 \mathrm{M}$ urea wash & 1015.2 & 92.3 & 246 & NE & NE & NE \\
\hline Pellet $4 \mathrm{M}$ urea wash & 1045.2 & 378 & 740 & NE & NE & NE \\
\hline Supernatant $8 \mathrm{M}$ urea solubilization & 905.8 & 264 & 589 & 86 & 69.8 & 79.5 \\
\hline Pellet $8 \mathrm{M}$ urea solubilization & 24 & 16.5 & 23 & NE & NE & NE \\
\hline
\end{tabular}

$\%$ of solubilization: The amount of protien in inclusion bodies in $4 \mathrm{M}$ urea pellet wash solubilized with $8 \mathrm{M}$ urea and present in the supernatant of 8 M urea.

(total protien $(\mathrm{mg})$ supernatant $8 \mathrm{M}$ urea/Total protein $(\mathrm{mg})$ pellet $4 \mathrm{M}$ urea) $\times 100$.

NE: non evaluated. 
Table 2: ESI-MS analysis of the tryptic peptides derived from the fused-protein

\begin{tabular}{|c|c|c|c|c|c|}
\hline$\#$ & Peptide sequencea) & $\mathrm{m} / \mathrm{z}$ exp. & $\mathrm{m} / \mathrm{z}$ theor. & $\mathrm{Zb})$ & Abs. Errorc) \\
\hline 1 & $\left.{ }_{11} \mathrm{~T}-\mathrm{K}_{33} \mathrm{~d}\right)$ & 908.81 & 908.83 & 3 & 0.02 \\
\hline 2 & ${ }_{40} \mathrm{M}-\mathrm{K}_{44}$ & 639.34 & 639.35 & I & 0.01 \\
\hline 3 & ${ }_{45} \mathrm{~F}-\mathrm{K}_{50}$ & 685.33 & 685.33 & I & 0.00 \\
\hline 4 & $\left.{ }_{56} A-R_{66}{ }^{f}\right)$ & 442.87 & 442.88 & 3 & 0.01 \\
\hline 5 & ${ }_{67} \mathrm{~A}-\mathrm{K}_{114}$ & 1781.52 & 1781.54 & 3 & 0.02 \\
\hline 6 & ${ }_{101} Q-K_{114}$ d), e) & 807.93 & 807.95 & 2 & 0.02 \\
\hline 7 & ${ }_{120} \mathrm{~N}-\mathrm{R}_{151^{\mathrm{f}}}$ & 921.14 & 921.17 & 4 & 0.03 \\
\hline 8 & ${ }_{166} S-R_{173}$ & 506.23 & 506.23 & 2 & 0.00 \\
\hline 9 & ${ }_{177} \mid-K_{181}$ & 511.31 & 511.28 & 1 & 0.03 \\
\hline 10 & ${ }_{190} \mathrm{Q}-\mathrm{R}_{220} \mathrm{f}$ & 1225.20 & 1225.23 & 3 & 0.03 \\
\hline 11 & ${ }_{221} \mathrm{~V}-\mathrm{R}_{227^{\mathrm{d}}}$ & 456.74 & 456.75 & 2 & 0.01 \\
\hline 12 & $\left.{ }_{228} \mathrm{M}-\mathrm{K}_{236} \mathrm{~d}\right)$ & 535.24 & 535.25 & 2 & 0.01 \\
\hline
\end{tabular}

a) The numbering in the sequences of peptides is according to the fused-protein sequence shown in the section Results and discussion.

b) Charge state of individual peptides.

c) Indicate the absolute mass difference between the theoretical and experimental molecular masses of the detected peptides.

d) Peptides sequenced by ESI-MS/MS.

e) Peptide originated by the non-specific cleavage of trypsin

f) Peptide containing free cysteine.

\section{a b}

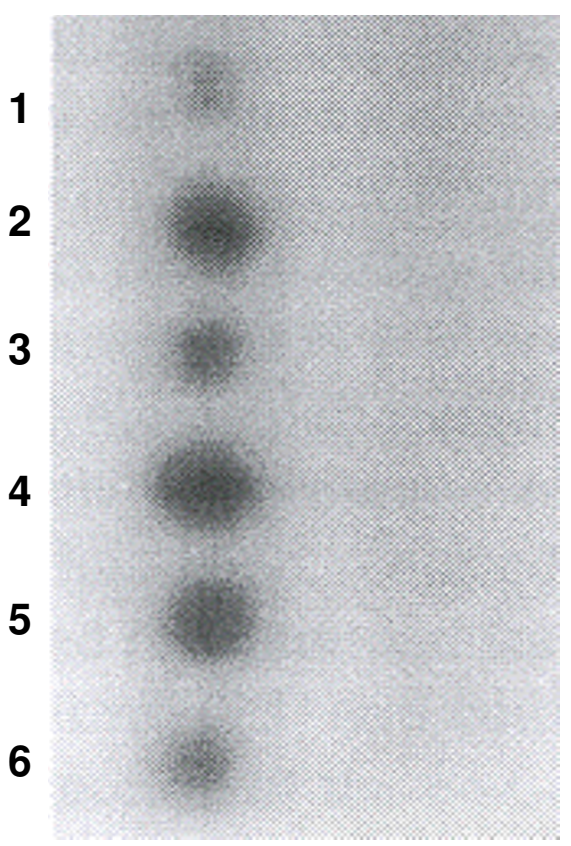

\section{Figure 3}

Binding assay of rhu 125 I-IFN- $\gamma$ labeled to recombinant chimeric protein using dot blot analysis. I $\mu \mathrm{l}$ aliquots of the eluted fractions from the gel filtration chromatography (rows I, 2, 3, 4, 5, 6) were applied to nitrocellulose membrane strips. The strips were incubated with IFN- $\gamma$ labeled with ${ }^{125}(35 \mu \mathrm{Ci} / \mu \mathrm{g})$ in the absence (lane $\left.a\right)$ and in the presence (lane $b$ ) of 100 fold excess of human IFN- $\gamma$. some of the sixty N-terminal amino acids of hu IL-2 (peptides 1-3, Table 2) and the extracellular domain of IFNGR1 were obtained (peptides 5-12, Table 2). The peptide (56A-R66, peptide \#4, Table 2) that links both proteins was also detected in the ESI-MS spectrum, confirming that a linker of four amino acids covalently binds these two proteins. The results shown in Table 2, account for $63 \%$ sequence coverage, which is a satisfactory result in the verification of primary structures of proteins extracted from SDS-PAGE. The protein tryptic spectrometric analysis showed the presence of fragments corresponding to the IL-2 N-terminal and IFN- $\gamma$ extracellular regions confirming the presence of the components of chimeric protein. In order to obtain a further confirmation that this chimeric protein is present in the digested band, the peptides corresponding to the four most intense signals in the ESI-MS spectrum (data not shown) were sequenced. Their ESI-MS/MS spectra were manually interpreted and partial sequences introduced into the PepSea database search program. Peptide 1 (Table 2) is contained in the N-terminal end of hu IL-2 whereas peptides 6, 11 and 12 (Table 2) belong to IFNGR1. These two polypeptides are fused into a single polypeptide chain that migrates as a $33 \mathrm{kDa}$ band as demonstrated by SDS-PAGE (Figure 4A). The aminoacid (in one letter code) sequence of the chimeric TH1 antagonist protein is the following: (bold letters indicated the peptides identified by Mass Spectrometric analysis, underlined is the linking peptide).

MAPTSSSTKKT $_{11}$ QLQLEHLLLDLQMILNGINNYK $_{33}$ NPKL TRM $_{40}$ LTFK $_{44} \mathrm{~F}_{45}$ YMPKK $_{50}$ ATELKH $_{56}$ LQCLAHMMSR $_{66} \mathbf{A}_{6}$ ${ }_{7}$ EMGTADLGPSSVPTPTNVTIESYNMNPIVYWEYQ $_{101}$ IM PQVPVFTVEVK $_{114}$ NYGVKN $_{120}$ SEWIDACINISHHYCNIS DHVGDPSNSWVR $_{151}$ VKARVGQKESAYAKS $_{166}$ EEFAVCR $_{1}$ ${ }_{73} \mathrm{DGKI}_{177} \mathrm{GPPK}_{181} \mathrm{LDIRKEEKQ}_{190} \mathrm{IMIDIFHPSVFVNGDE}$ 
A B

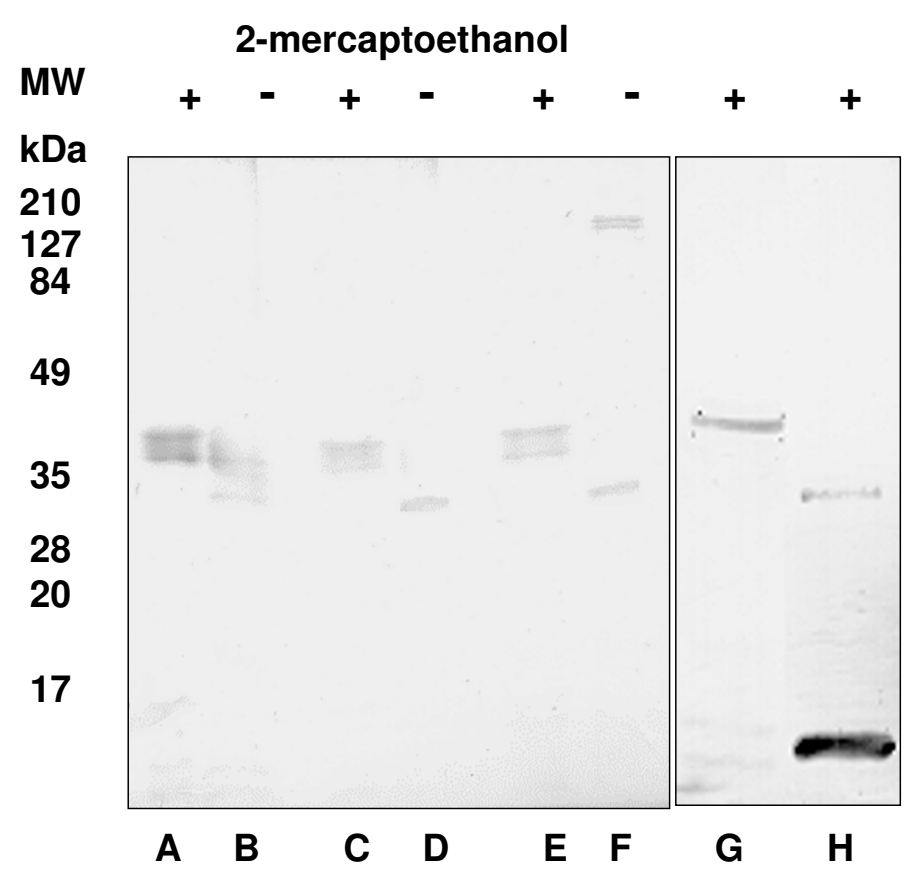

Figure 4

Electrophoretic mobility of recombinant chimeric protein in reduced and non-reduced conditions. Panel A: The antagonist was identified in a Western blot using a rabbit anti-IL-2 polyclonal antibody. The analyzed THI antagonist preparations were those obtained from the $8 \mathrm{M}$ urea extraction, (lanes $a$ and $b$ ), gel filtration fraction in $4 \mathrm{M}$ urea (lanes $c$ and $d$ ) and after dialysis against PBS (lanes e and f). Panel B: Western blot to identify the THI antagonist after dialysis against PBS (lane g) and IL-2 (lane $h$ ) in reduced conditions using the anti-IL-2 antibody.

QEVDYDPETTCYIR $_{220} \mathrm{~V}_{221} \mathrm{YNVYVR}_{227} \mathrm{M}_{228}$ NGSEIQYK $_{23}$ ${ }_{6}$ ILTQKEDDCDEIQCQLAIPVSSLNSQYCVSAEGVLHVW GVTTEKSKEVCITIFNSSIKG.

The analyzed results are compatible with the recombinant chimeric antagonist protein comprising amino acids 1-60 from human IL-2 N-terminal followed by a peptide followed by a peptide Ala-Hist-Met-Met (underline in the above aminoacid sequence) and the 228 aminoacids from the human IFNGR1. This protein contains one cysteine from IL-2 N-terminal and 8 cysteine residues from IFNGR1 extracellular region. For comparison, the chimeric protein sequence with the known IL-2 and IFNGR1 sequences see the following access numbers for IL-2 [NCBI protein: CAA07317] and for IFNGR1 [NCBI protein: CAI21593]. The reported sequences in the PubMed databases include the amino acids sequences corresponding to signal peptide at the beginning of the sequences. It must be taken in account that, the cloned by us sequences correspond to the mature protein without signal peptide.
THI chimeric antagonist biological activities IL-2 antagonist/agonistic action

The biological activity of the TH1 antagonist protein was tested in vitro in an assay examining the capacity of the molecule to inhibit the proliferation of T cells in response to rhu IL-2. The descriptive statistic indicates that chimeric protein reduced the activity of IL-2 corresponding to 27.7 IU/mL (median: 28.2, minimum: 20.0, maximum: 34.8 and std. dev 7.6), to $7.5 \mathrm{IU} / \mathrm{mL}$ (median 7.9, minimum: 4.2, maximum: 10.0 and std. dev. 2.5), a difference statistically significant with a $\mathrm{p}=0.02$ (Figure 5 and 6A). The chimera shares also IL-2 agonistic action, as it sustained the growth of murine $\mathrm{T}$ cells dependent on exogenous IL2 (Figure 6A, 6B). In this case, the absorbance measured during the proliferative assay for CTLL-2 cells incubated with $2.8 \mathrm{ng} / \mathrm{mL}$ of IL-2 has a mean value of 1.6, while for $1.5 \mu \mathrm{g} / \mathrm{mL}$ of TH1 antagonist molecule the absorbance was approximately the half (Figure 6B).

As mentioned before, the high-affinity receptor for IL-2 is composed of three subunits, IL-2R $\alpha$, IL-2R $\beta$ and IL-2R $\gamma$. Moreover, the $\mathrm{N}$-terminal IL-2 region contains all the ami- 


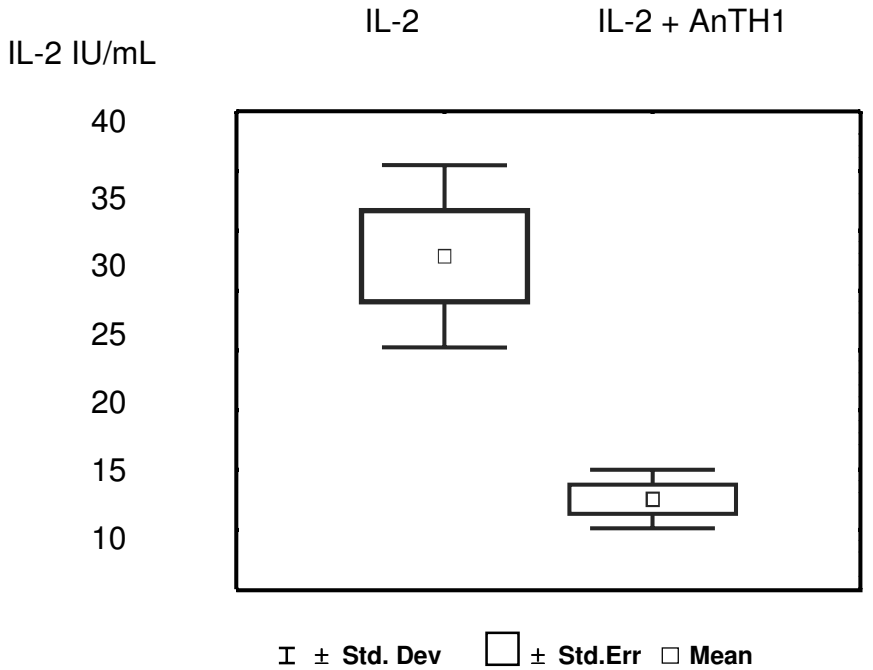

\begin{abstract}
Figure 5
Inhibition of growth stimulating activity of rhu IL-2 on the mouse cell line CTTL-2 by recombinant chimeric protein. The data are results from 3 independent experiments. The observed difference proved to be statistically different ( $P$ $<0.05)$ by the Kruskal-Wallis test. IL-2 dilution I:40 000 correspond to $25 \mathrm{IU} / \mathrm{mL}(2.8 \mathrm{ng} / \mathrm{mL})$. Group I: IL-2, group 2: IL-2 + THI antagonist. Results expressed in international units of IL-2 where I IU is defined as the amount of IL-2 that elicits a $50 \%$ increase in cell growth in a cell base bioassay.
\end{abstract}

noacids interacting with the IL-2R $\alpha$ subunit (Lys 35, Arg 38, Phe 42, and Lys 43) and those contacting the IL-2R $\beta$ subunit (Asp 20 and others) [33]. Then the antagonism for the biological activity of IL-2 could be explained by the interaction of IL-2 regions in the fragment of the antagonist described as contacting with the indicated IL-2 receptor subunits. Probably the first sixty aminoacid of $\mathrm{N}$ terminal region of IL-2 can interfere with high-affinity binding of completely mature IL- 2 molecule to its membrane receptor. Otherwise, in the absence of IL-2, the 60aminoacid N-terminal IL-2 fragment from TH1 antagonist chimera might exert the IL-2 agonistic activity. It has been reported that the $\mathrm{N}$-terminal aminoacid stretch $(1-30)$ from IL-2 binds to IL-2R $\beta$ and reproduce some of the IL-2 biological functions, as lymphokine activated killer (LAK) cells activation, induction of IFN- $\gamma$ production and T cell proliferation stimulation $[34,35]$. More work is needed to precisely demonstrate its dual effects.

\section{THI anatagonist neutralization of IFN- $\gamma$ activities}

In order to test for inhibition of antiproliferative action of rhu IFN- $\gamma$ we used HEp-2 cells, known to be highly susceptible to growth inhibition by IFN- $\gamma$. During antiproliferative activity assays 2,4 and $8 \mathrm{ng} / \mathrm{ml}$ of IFN- $\gamma$ inhibited the growth of HEp-2 cells by approximately $60 \%$. Addition of $50 \mu \mathrm{g} / \mathrm{mL}$ of TH1 antagonist to 2 or $4 \mathrm{IU} / \mathrm{mL}$ of IFN- $\gamma$ fully restored proliferation of cells. Neutralization of $8 \mathrm{IU} / \mathrm{mL}$ (Figure 7A) was incomplete. The data demonstrated that the antagonist has the capacity to inhibit the antiprolifer- ative action of IFN- $\gamma$. However, this effect is obtained at a low molar ratio. This may be due to the high sensitivity of the HEp-2 cell line to growth inhibition of IFN- $\gamma$, as evidenced by the data of figure 7 , showing that $2 \mathrm{IU} / \mathrm{mL}$ of IFN- $\gamma$ alone had almost a saturating antiproliferative effect on HEp-2 cells.

Treatment of Colo 205 with IFN- $\gamma$ resulted in the induction of a HLA-DR, a class II MHC antigen, one of the properties of IFN- $\gamma$ that account for its immunomodulatory action. The stimulation of HLA-DR expression by IFN- $\gamma$ $(0.5 \mu \mathrm{g} / \mathrm{mL})$ was significantly regulated down $\left({ }^{*} \mathrm{p}=0.03\right)$ in the presence of the TH1 antagonist $(1.5 \mu \mathrm{g} / \mathrm{mL}$ ) (Figure $7 \mathrm{~B})$. Thus, in the experiments designed to test the in vitro biological activities of recombinant TH1 antagonist, the molecule inhibited the antiproliferative and immunomodulatory activities of IFN- $\gamma$ and the proliferate activity of IL-2. Based on these in vitro biological activities, the antagonist demonstrated a high potential to interfere with the in vivo IL-2 and IFN- $\gamma$ functions during the activation of the immune system, a characteristic of the inflammatory and autoimmune conditions. Nonetheless, in vivo immune response is essentially normal in mice lacking IL2 signaling [22]; therefore, the antagonist may not strongly impact TH1 response in regard to IL-2 during early in immune response. However, the antagonist may influence later in the immune response because; IL-2 contributes to T-cell immunity in vivo and seems to be more important during the later stages of immune responses. It 


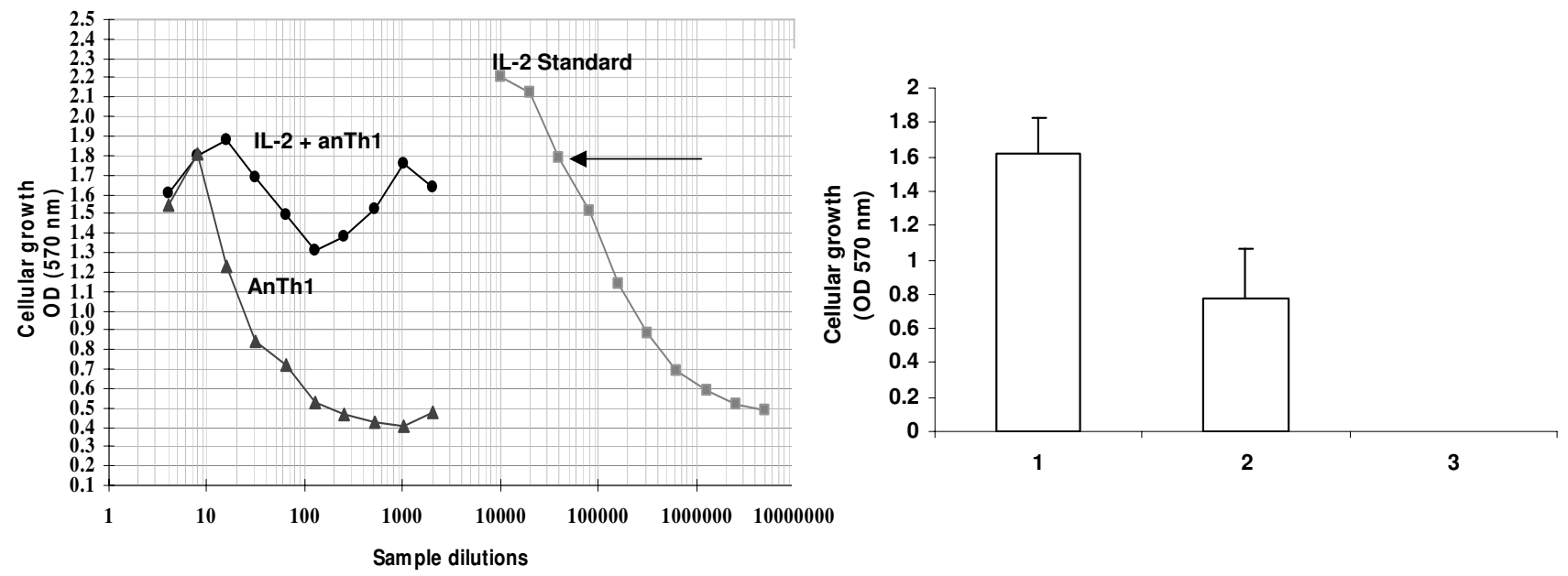

Figure 6

IL-2 antagonistic/agonistic biological activities of the recombinant chimeric protein. Panel A: Antagonistic/agonistic biological activities. The figure shows plots of a representative CTLL-2 proliferative assay showing the OD of tested samples in each of the evaluated serial dilutions. The IL-2 used for the experiments is the IL-2 international standard (ST-IL22010397, $880000 \mathrm{UI} / \mathrm{mL}$ ). The arrow shows the OD of IL-2 dilution to test in the presence of serial dilutions of recombinant protein. Panel B: Stimulation of T cells proliferation by THI antagonist. Bar I: $2.8 \mathrm{ng} / \mathrm{ml}$ of IL-2 (dilution I:40000), bar 2: I.5 $\mu$ g/ $\mathrm{ml}$ of AnTHI, bar 3: culture medium without IL-2.

has been shown to contribute to the type or magnitude of effectors cells that are produced and to be involved in its migration or proliferation in non-lymphoid tissue.

The TH1 antagonist has other potentially useful characteristics. Beside its capacity of interferes with IL-2, it shows IL-2 agonistic activity, a property that during clinical application might allow to avoid deactivation of the immune system, an adverse effect that is characteristic of current anti-cytokine antagonists therapies, and favors the occurrence of opportunistic infections, demyelization and congestive heart failure [36,37]. Furthermore, because IL$2 \alpha \mathrm{R}$ subunit is expressed only in activated $\mathrm{T}$ cells, the antagonist might be targeted mainly to this $\mathrm{T}$ cell subset or to cells expressing the IL-2 $\beta \mathrm{R}$ subunit. Thereby, the agent might be concentrated in the extracellular milieu where activated $\mathrm{T}$ cells are abundant.

The agonistic function of the chimera may also offer the opportunity to promote the IL-2 dependent regulatory function of CD4 (+) CD25 (+) T cells, which has been described as critical in the control of autoimmune diseases[22], in the absence of endogenous IL-2 and likely interfere with it in the presence of high endogenous IL-2 levels. Nonetheless, the suppressive efficacy of Tr cells isolated from mice subjected to various treatments correlated closely with suppression of IFN- $\gamma$ and IL-2 production by the CD25-effector T cells [38]. In vivo confirmation of these potential properties of TH1 antagonist will offer new opportunities to treat several disease conditions accessible with this therapeutic approach.

\section{Conclusion}

We were able to construct and purified a recombinant chimeric antagonist composed by a 60 amino acid fragment of the N-terminal region of human IL-2 fused to the N-terminal of the extracellular region of the alpha subunit of the gamma IFN- $\gamma$ receptor was obtained. The chimeric protein conserves the physicochemical abilities of their components. This means, the IFN- $\gamma$ receptor tail is able to recognize the IFN- $\gamma$ and in correspondence neutralizes two biological activities of IFN- $\gamma$, its antiproliferative action on HEp-2 cell line, and the stimulation of HLA-DR in Colo 205 cells. These data evidenced that the construction is compatible with the active conformation of the IFNGR1 extracelluar region. Others experiments confirmed that the IL-2 fragment of 60 aminoacids from the IL-2 N-terminal is in a correct conformation because elicit a classical well recognized property of IL-2, the stimulation of growth of CTTL-2 cell line dependent on IL-2 for growth and survival. The data evidenced and demonstrated that the components are functional in term of their structure as evidenced from the biological activities they have. 
A
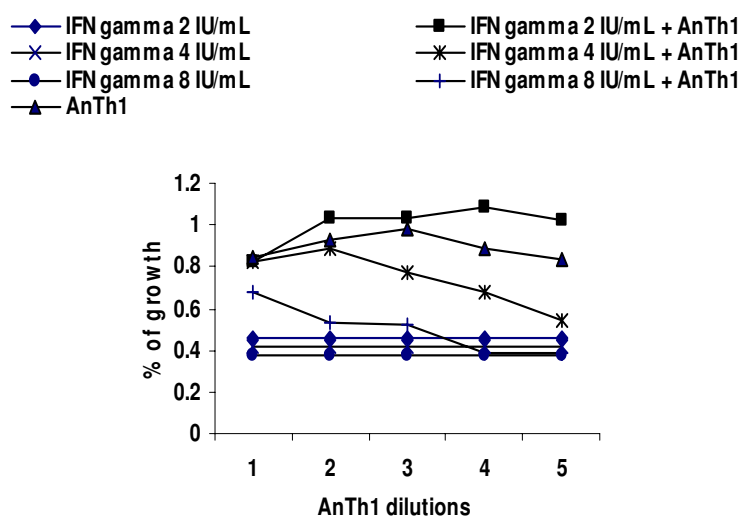

B

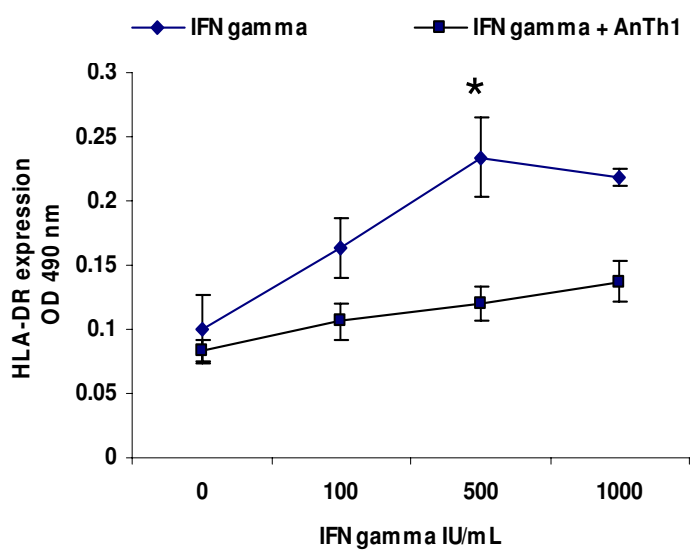

\section{Figure 7}

Neutralization of biological activities of rhu IFN- $\gamma$ by recombinant chimeric protein. Panel A: Inhibition of antiproliferative activity of IFN- $\gamma$. The inhibition of antiproliferative action of $4 \mathrm{IU} / \mathrm{ml}$ of IFN- $\gamma$ by $50 \mu g / \mathrm{ml}$ AnTHI proved to be statistically different $(p<0.05)$ by the Kruskal-Wallis test. The data are results from 3 independent experiments. The dilutions tested for the antagonist were: I (I:4), 2 (I:8), 3 (I:I6), 4 (I:32), and $5(\mathrm{I}: 64)$. The OD $580 \mathrm{~nm}$ of cells without IFN- $\gamma$ at the beginning of the experiment was 0.139 and after 72 hours on culture was 1.068 . Panel B: Inhibition of the IFN- $\gamma$ induced HLA-DR by the AnThI. The inhibition of IFN- $\gamma(500 \mathrm{IU} / \mathrm{mL}) \mathrm{HLA}-\mathrm{DR}$ stimulation by $1.5 \mu \mathrm{g} / \mathrm{ml}$ AnTh I proved to be statistically different (P $<0.05)$ by the Kruskal-Wallis test. The data are the results from 3 independent experiments. The amount of IFN- $\gamma$ was denoted as IU of antiviral activity, where I IU is defined as the inverse of the dilution that conferred $50 \%$ protection to the monolayer of cells infected with a virus.

\section{Methods Cells}

Raji (human Burkitt lymphoma, ATCC: CCL-86) and Jurkat (human acute T-cell leukemia, ATCC: TIB-152) cells were grown in RPMI 1640 supplemented with $10 \%$ fetal calf serum (FCS, Gibco BRL, LIFE TECNOLOGIES ${ }^{\mathrm{TM}}$ ) in plastic flasks with gentle agitation at $37^{\circ} \mathrm{C}$ and $5 \% \mathrm{CO}_{2}$, as source of poly-A mRNA. Murine T-cells CTLL-2 (cytotoxic T cell, ATCC: TIB-214), human HEp-2 (laryngeal carcinoma, ATCC: CCL23) and Colo 205 (human colorectal adenocarcinoma, ATCC: CLL-222) cell lines were used to evaluate the biological activity of the antagonist. Cells were cultured in RPMI 1640 (CTLL-2, Colo 205) and MEMCANE (HEp-2) containing gentamycin $(50 \mu \mathrm{g} / \mathrm{mL})$ and $10 \% \mathrm{FCS}$ at $37^{\circ} \mathrm{C}$ in a humidified $5 \% \mathrm{CO}_{2}$ environment. E. coli cells W3110 P3 were used for pHu (AnTH1) plasmid expression.

\section{Isolation of CDNA coding for IL-2 N-terminal and IFNGRI} extracellular region

Poly-A mRNA purified from $2 \times 10^{8}$ Jurkat and Raji cells, respectively, using the MessageMaker ${ }^{\circledast}$ mRNA Isolation System (Invitrogen Life Technologies) was employed for cDNA RT-PCR amplification. 1-2 $\mu$ g poly-A mRNAs were reverse transcribed with GeneAmp RNA PCR kit (Perkin Elmer Cetus, Norwalk, Conn.) using random hexamers. The specific primer pairs were the following (overlapping nucleotides are underlined): 5'CCATGACCTACTTTCAAGTTCTACAAAG3' and 5'CATCATATGGGTCTAGACACTGAAGATGTTTC3' for the amplification of IL-2 N-terminal, and 5'CCCATATGATGAGCAGGGCTGAGATGGGC3' and 5'GATCCTTATTTTATACTGCTATTGAAAATG3' for the IFNGR1 extracellular region. Primers for the second round PCR were: 5'CCATGGCACC TACTTTCAAGTTCTACAAAG3' and 5'GGATCCTTATTTTATACTGC TATTGAAAATG 3'. 
In brief, first-strand DNA was synthesized in a final volume of $20 \mu \mathrm{L}$ from $1 \mu \mathrm{g}$ poly-A mRNA in DEPC- $\mathrm{H}_{2} \mathrm{O}$ using $5 \mathrm{mM} \mathrm{MgCL}_{2}, 1 \mathrm{mM}$ dNTP, $1 \mathrm{U} / \mu \mathrm{L}$ Rnase inhibitor, $2.5 \mathrm{U} / \mu \mathrm{L} M u L V$ reverse transcriptase, $2.5 \mu \mathrm{M}$ random hexamers, $0.75 \mu \mathrm{M}$ primers, and 1X PCR buffer II. The mixture was incubated in a DNA Thermal Cycler (MJ Research, Inn.) at $25^{\circ} \mathrm{C}$ for 10 minutes, then 1 hour at $42^{\circ} \mathrm{C}$ followed by 5 minutes at $99^{\circ} \mathrm{C}$ and then frozen until use. Complementary DNA $(10 \mu \mathrm{l})$ were mixed as recommended by providers with the appropriately specific primers and reagents $(2 \mathrm{mM} \mathrm{MgCl} 2,2.5 \mathrm{U} / 100 \mu \mathrm{L} \mathrm{Ampli-}$ Taq DNA polymerase, $0.15 \mathrm{mM}$ specific primers and $1 \mathrm{X}$ PCR Buffer II). Amplification started with 5 minutes denaturation at $94^{\circ} \mathrm{C}$, followed by 30 PCR cycles. Each cycle consisted of 60 seconds at $94^{\circ} \mathrm{C}$ for denaturation, $40 \mathrm{sec}-$ onds for annealing (temperature depended on the primers were used), and 40 seconds at $72^{\circ} \mathrm{C}$ for extension. Final extension lasted 5 minutes at $72^{\circ} \mathrm{C}$. Twenty five percent of the RT-PCR reaction $(5 \mu \mathrm{l})$ was transferred to a second round reaction mix with the second round primers and reagents in the same concentrations as described for PCR. The second round PCR (25 cycles) was done using the same cycle schedule.

\section{Construction of the THI antagonist expression vector} The pTPV-1 plasmid, supplied by the Biomedical Research Division at CIGB, was employed as expression vector. It carries the E. coli tryptophan promoter, the bacteriophage T4 terminator and the ampicillin resistance gene. PTPV-1 vector was digested stepwise with the NcoI and BamHI enzymes. Second PCR amplified cDNA was digested with the BamHI enzyme and processed to eliminate the enzyme and the buffer. Then PCR product was digested with NcoI, and processed as described before. Finally, the vector and the amplified gene fragment were ligated using the T4 ligase enzyme.

\section{Sequencing of the pHu (AnTHI) plasmid}

The sequencing of $\mathrm{pHu}$ (AnTH1) plasmid was done using the Taq Dye Deoxy terminator cycle sequencing kit (Applied Biosystems). One $\mu \mathrm{g}$ of $\mathrm{pHu}$ (AnTH1) plasmid was used as template and annealed with $10 \mathrm{ng}$ forward or reverse primers, which hybridize with a promoter region of expression vector. After the separation of unincorporated dye terminators and primers, the products were dried in SpeedVac centrifuge, resuspended in loading buffer, heat denatured and immediately loaded on acrylamide gel in an automated DNA sequencer.

\section{Expression of the recombinant protein}

E. coli cells, strain W3110P3, containing pHu (AnTH1) plasmid were grown at $37^{\circ} \mathrm{C}$ in $\mathrm{LB}$ medium with $50 \mu \mathrm{g} /$ mL tryptophan and $100 \mu \mathrm{g} / \mathrm{mL}$ ampicillin until the cells reached an optical density (OD) of 2.0 at $620 \mathrm{~nm}$. Then cells were inoculated in M9 medium with $4 \%$ glucose without tryptophan and $50 \mu \mathrm{g} / \mathrm{mL}$ ampicillin to a final OD of 0.25 and grown during 8 hours at $37^{\circ} \mathrm{C}$ with agitation. Cells were harvested and kept frozen $\left(-20^{\circ} \mathrm{C}\right)$ for future processing.

\section{Extraction of $E$. coli cells and refolding}

To suspend the cells, $10 \mathrm{~mL}$ of $10 \mathrm{mM}$ Tris buffer $\mathrm{pH} 7.2$, $1 \mathrm{mM}$ EDTA was added per $\mathrm{g}$ of $E$. coli cells. The cells were digested with lysozyme and the pellet from the digestion was washed in a Polytron homogenizer (IKA, Germany) in $50 \mathrm{mM}$ Tris pH 7.2, $1 \mathrm{mM}$ EDTA containing increasing urea concentrations (from 1 to $8 \mathrm{~mol} / \mathrm{L}$ ). Cell suspensions were centrifuged at $12000 \mathrm{rpm}$ at $4^{\circ} \mathrm{C}, 5 \mathrm{~min}$. and supernatants discarded. The pellet from $4 \mathrm{M}$ urea wash was finally extracted in a Polytron homogenizer with $10 \mathrm{mM}$ Tris buffer pH 7.2, $1 \mathrm{mM}$ EDTA containing $8 \mathrm{~mol} / \mathrm{L}$ urea (extraction buffer). Cell homogenate was centrifuged at $12000 \mathrm{rpm} 5 \mathrm{~min} .4^{\circ} \mathrm{C}$ and supernatant decanted and stored at $-20^{\circ} \mathrm{C}$ until refolding. Supernatant from the $8 \mathrm{M}$ urea extraction $(150 \mathrm{~mL})$ was loaded on a Sephadex G100 column (K9/60 (Pharmacia, Uppsala), equilibrated with $50 \mathrm{mM}$ Tris HCL pH 7.4 containing $4 \mathrm{M}$ urea. The elution was performed in the same buffer at $3 \mathrm{~mL} /$ minute. Eluted fractions containing the recombinant protein were pooled and dialyzed against a buffer containing 0.1 Tris$\mathrm{HCl}, \mathrm{pH}$ 9.0. The dialysis was then continued against phosphate buffered saline (PBS), pH 7.4.

\section{Ligand-bloting, SDS-PAGE, immuno-blot}

For ligand blot, $5-\mu \mathrm{L}$ fractions from gel filtration chromatography containing folded AnTH1 recombinant protein, were directly applied to nitrocellulose strips and incubated with $10 \%$ defatted milk during $2 \mathrm{~h}$ at room temperature. After washing with PBS containing 0.05\% Tween 20 (PBS-T), the strips were incubated with 125 -I labed recombinant IFN- $\gamma$, without or in the presence unlabed recombinant IFN- $\gamma$. Finally, the strips were thrice washed with PBS-T and exposed for autoradiography. For SDS-PAGE the samples were loaded in sample buffer with or without reducing agents. Bands were visualized by Coomassie Blue R-250 (Sigma) staining.

For immunoblotting samples were loaded as for SDSPAGE. After blotting, nitrocellulose strips were incubated with $10 \%$ defatted milk during $2 \mathrm{~h}$ at room temperature, washed (as for ligand blot) and incubated with mouse anti-IFNGR1 monoclonal antibody R99 ( $9 \mu \mathrm{g} / \mathrm{mL})$ or rabbit polyclonal antibody against human IL-2 protein, washed, incubated with anti-mouse or anti-rabbit (IgG)peroxidase conjugate in $1 \%$ defatted milk and finally washed. Then, the strips were incubated with developing solution $\left(\mathrm{H}_{2} \mathrm{O}_{2}, 5 \mathrm{mg} / \mathrm{mL}\right.$, o-phenylendiamine, and 15\%). 


\section{Aminoacid sequence. In-gel digestion}

An aliquot $(0.5 \mu \mathrm{g})$ of purified protein was analyzed by SDS-PAGE and reversed-stained with Zn-imidazol [39]. The band was excised and incubated with a $1 \%$ citric acid solution during 5 minutes until complete destaining and incubated another 10 minutes in water to remove the excess of chelating agent. The transparent band was additionally cut in approximately one $\mathrm{mm}^{3}$ cubes dehydrated in a $90 \%$ acetonitrile aqueous solution without TFA, and completely dried in a SpeedVac centrifuge. The gels pieces were rehydrated in $20 \mu \mathrm{L}$ of $50 \mathrm{mM} \mathrm{NH}_{4} \mathrm{HCO}_{3}$ solution containing $12.5 \mathrm{ng}$ of trypsin, sequencing grade (Promega, USA). The in-gel digestion was incubated overnight at $37^{\circ} \mathrm{C}$ in a thermomixer (Eppendorf, USA). Additionally, $20 \mu \mathrm{L}$ of $50 \mathrm{mM} \mathrm{NH}_{4} \mathrm{HCO}_{3}$ solution were added and incubated further for $45 \mathrm{~min}$. Tryptic peptides were extracted using ZipTips C18 (Millipore, USA) previously activated and equilibrated as recommended by the manufacturer. Twenty loading cycles were carried out for extracting tryptic peptides. The digest was acidified with formic acid, incubated 45 minutes at room temperature and another twenty loading cycles were achieved. The Ziptips were washed extensively using a $5 \%$ formic acid solution and proteolytic peptides eluted in $2 \mu \mathrm{L}$ of $60 \%$ acetonitrile containing $1 \%$ formic acid.

\section{Mass spectrometry}

The Electrospray ionization (ESI-MS) mass spectra were acquired using a hybrid quadrupole orthogonal acceleration tandem mass spectrometer QTOF from Micromass (Manchester, UK) fitted with a Z-spray nanoflow electrospray ion source. The mass spectrometer was operated with a source at $80^{\circ} \mathrm{C}$ and a drying gas flow of $50 \mathrm{~L} / \mathrm{h}$. Two $\mu \mathrm{L}$ of the tryptic peptides were loaded onto the borosilicate nanoflow tip and $900 \mathrm{~V}$ and $35 \mathrm{~V}$ potentials were applied to nanoflow tip and entrance cone, respectively. To obtain information on peptide sequence, the ESI-MS/ MS spectra were acquired as described previously [40]. Data acquisition and processing were performed using the MassLynx system ( $\mathrm{v}$ 3.5) from Micromass. The most intense signals observed in the ESI-MS spectra were sequenced by MS/MS, sequence tags were manually extracted and used to identify the proteins by Peptide Search program [41]. Peptide mass tolerance was 2 Da in order to identify peptides containing deamidated asparagines residues.

\section{Inhibition of recombinant rhu IL-2 biological activity}

The biological activity of rhu IL-2 was assessed as described [42] using IL-2-dependent murine $\mathrm{T}$ lymphocyte cell line CTLL-2 [43]. Cells were grown in RPMI1640 medium containing $1 \mathrm{mM}$ pyruvate, $2 \mathrm{mM} \mathrm{L-}$ glutamine, $40 \mathrm{mM}$ HEPES, $100 \mathrm{U} / \mathrm{mL}$ penicillin, $50 \mu \mathrm{g} /$ mL streptomycin, $50 \mu \mathrm{M} 2$ - mercaptoethanol and $10 \%$ FCS supplemented with $8 \mathrm{U} / \mathrm{mL}$ rhu IL-2 (Heber Biotec,
Havana; $1.2 \times 10^{7} \mathrm{IU} / \mathrm{mg}$ ). Before use, cells were washed thrice, resuspended in complete culture medium without IL-2 and incubated during $1 \mathrm{~h}$ at $37^{\circ} \mathrm{C}$ in a humidified $5 \%$ $\mathrm{CO}_{2}$ atmosphere. Cells were suspended at a density of $4 \times$ $10^{5}$ cells $/ \mathrm{mL}$, and distributed into 96-well microtiter plates (100 $\mu \mathrm{L}$ per well) already containing $100 \mu \mathrm{L}$ of twofold serial dilutions of rhu IL-2 or samples, in complete medium. Samples consisted of a constant amount of rhu IL-2 containing serial dilutions of the antagonist. Following $36 \mathrm{~h}$ of incubation at $37^{\circ} \mathrm{C}, 20 \mu \mathrm{L}$ of $5 \mathrm{mg} / \mathrm{mL}$ of MTT were added and plates incubated for $4 \mathrm{~h}$ in the same environment. Finally, $50 \mu \mathrm{L}$ of $10 \%$ SDS/ $0.1 \mathrm{~N} \mathrm{HCl} / 50 \%$ isopropylalcohol solution were added per well, the plates agitated for $1 \mathrm{~h}$ at $37^{\circ} \mathrm{C}$, and the absorbance readed at 570 nm using a microplate reader (Tecnosuma, Havana). Results were expressed as hu IL-2 units.

\section{Inhibition of rhu IFN- $\gamma$ antiproliferative action}

HEp-2 at $2.5 \times 10^{3}$ cells/mL were seeded in 96-well microtiter plates (COSTAR, Cambridge), cultured in MEMCANE containing $50 \mu \mathrm{g} / \mathrm{ml}$ gentamycin and 10\% FCS, at $37^{\circ} \mathrm{C}$ in a humidified $5 \% \mathrm{CO}_{2}$ environment. Serial dilutions in MEM-CANE medium with $10 \%$ FCS of chimeric recombinant protein samples were tested. Samples were mixed with an equal volume of medium containing appropriated amounts (see figures notes) of rhu IFN- $\gamma$ (Heber Biotec, Havana; $1.0 \times 10^{7} \mathrm{IU} / \mathrm{mg}$ ). After adding the samples, monolayers were incubated during $72 \mathrm{~h}$ at $37^{\circ} \mathrm{C}$, $5 \% \mathrm{CO}_{2}$. The amount of growing cells in triplicate cultures at each point was determined by Crystal Violet staining, and absorbance measured at $490 \mathrm{~nm}$ using the microplate reader. The result is defined as \% of growth as follows:

$\%$ of growth $=($ AT72h-ACOh/AC72h-ACOh $) \times 100$.

AT72h $=$ Absorbance from treated culture at $72 \mathrm{hr}$.

$\mathrm{AC} 72 \mathrm{~h}=$ Absorbance from control culture at $72 \mathrm{hr}$.

$\mathrm{ACOh}=$ Absorbance from culture just prior to the addition of IFN.

\section{Inhibition of HLA expression}

The biological activity of TH1 antagonist was assessed further by testing its ability to prevent IFN- $\gamma$ from inducing expression of HLA-DR. A bio-ELISA assay according to the method of Gibson and colleagues [44] was carried out. Colo 205 cells were grown to confluence in RPMI 1640 containing 10\% FCS, trypsinized and seeded in 96-well tissue culture plates at a density of $2.5 \times 10^{5}$ cells/well in $0.1 \mathrm{~mL}$ of RPMI 1640 containing $10 \%$ FCS and finally incubated for $12 \mathrm{~h}$ at $37^{\circ} \mathrm{C}$ in $5 \% \mathrm{CO}_{2}$. Culture media containing the rhu IFN- $\gamma$ samples and mixtures of rhu IFN- $\gamma$ and antagonist protein were added in a $0.1 \mathrm{~mL}$ vol- 
ume to the wells containing Colo 205 cells, and then incubated for $1 \mathrm{~h}$ at $37^{\circ} \mathrm{C}$. Following incubation, the media was removed and wells washed three times with culture media. Fresh culture media $(0.2 \mathrm{ml} /$ well $)$ was added and plates incubated for $48 \mathrm{~h}$ at $37^{\circ} \mathrm{C}$ to allow for induction of HLA/DR antigen. Then, the wells were washed with PBS and fixed for 2 min with ice-cold anhydrous ethyl alcohol. After the alcohol was removed, the wells were washed with PBS and incubated for $1 \mathrm{~h}$ at room temperature with mouse monoclonal anti-HLA/DR (DAKO, California) antibody diluted in PBS containing $0.5 \%$ bovine serum albumin. PBS was used to wash the wells, and peroxidaselabeled goat anti-mouse IgG was added to each well for 1 $\mathrm{h}$ at room temperature. The wells were washed three times with PBS and then developed as described for the ELISA plates.

\section{Authors' contributions}

IBR has made substantial contributions to conception and design of chimera and participated in the cloning, expression and purification of the recombinant protein and in the design of biological activities tests. YTR carried out the purification process characterization and the assays for inhibition of biological activities of IFN- $\gamma$. EBG carried out sequencing and contribute to evaluation of biological activities. GPR contribute to cloning and genetic construction of recombinant protein. OFB carried out purification and refolding of the recombinant protein. LJG contributed to amino acid sequencing. HJP carried out the assays for the antagonistic/agonist IL-2 activities. PLS has been involved in critically revising the manuscript and supervised the work concerning the biological activity evaluation. All authors read and approved the final manuscript.

\section{Acknowledgements}

We thank Dr. Manuel Araña for critical reading of the manuscript and Professors Marco Soria and Alfons Billiau for reading and suggestions. We thank the technical assistance of Lisset Rodriguez and Iraida de León. The authors received funds from Government source.

\section{References}

I. Farrar MA, Schreiber RD: The molecular cell biology of interferon gamma and its receptor. Ann Rev Immunol 1993, I I:57|-6II.

2. Chan SH, Kobayashi M, Santoli D, Perussia B, Trinchieri G: Mechanisms of IFN-induction by natural killer cell stimulatory factor (NKSF/IL-I2): role of transcription and mRNA stability in the synergistic interaction between NKSF and IL-2. J Immunol 1992, I 48:92-98.

3. Trinchieri G, Perussia B: Immune Interferon: A pleiotropic lymphokine with multiple effects. Immunol Today 1985, 6: I3 I-I36.

4. Revel M, Chebath J: Interferon-activated genes. TIBS 1986, I I:166-170.

5. Bach EA, Aguet $M$, Schreiber RD: The IFN gamma receptor: $\mathbf{A}$ paradigm for cytokine signaling. Annu Rev Immunol 1997, | 5:563-59|.

6. Sogabe S, Stuart F, Henke Ch, Bridges A, Williams G, Birch A, Wikler KF, Robinson JA: Neutralizing epitopes on the extracellular interferon gamma receptor (IFN gamma $R$ ) alpha chain characterized by homolog scanning mutagenesis and $X$-ray crystal structure of the A6 Fab-IFNgamma R I- 108 complex. J Mol Biol 1997, 273:882-897.
7. Bello I, Perez A, Torres AM, Hernández MV, Lopez-Saura P: High levels of soluble IFN- $\gamma$ receptor $\alpha$ chain in the plasma of rheumatoid arthritis patients. Biotherapy 1998, I I:53-57.

8. Heremans H, Van J, Dillen C, Dijkmans R, Billiau A: Interferon gamma, a mediator of lethal lipopolysaccharide-induced schwartzman-like shock reactions in mice. J Exp Med 1990, | 7 |: |853-|869.

9. Landolfo S, Cofano F, Giovarelli M, Prat M, Cavallo G, Forni G: Inhibition of interferon gamma may suppress allograft reactivity by $\mathbf{T}$ lymphocytes in vitro and in vivo. Science 1985, 229: $176-179$.

10. Didlake RH, Kim EK, Sheehan K, Schreiber RD, Kahan B: Effect of combined anti-gamma interferon antibody and cyclosporine theraphy on cardiac allograft survival in the rat. Transplantation 1988, 45:222-223.

II. Campell IL, Oxbrow L, Koumanidis M, Harrison LC: IFN gamma induces islet cell MHC antigens and enhances autoimmune streptozotocin-induced diabetes in the mouse. J Immunol 1988, I40: I I II-III6.

12. Chang I, Cho N, Kim JY, Kim E, Woo JE, Nam JH, Kim SJ, Lee MS: Role of calcium in pancreatic islet cell death by IFN-gamma/ TNF-alpha. J Immunol 2004, I 72:7008-70I4.

13. Jacob $\mathrm{CO}$, vander Meide $\mathrm{PH}, \mathrm{McDevitt} \mathrm{Ho}$ : In vivo treatment of (NZBxNZW) FI lupus like nephritis with monoclonal antibody to gamma interferon. J Exp Med 1987, I 66:798-803.

14. Hasegawa K, Hayashi T, Maeda K: Promotion of lupus in NZB $\times$ NZWFI mice by plasmids encoding interferon (IFN)gamma but not by those encoding interleukin (IL)-4. J Comp Pathol 2002, I 27:I-6.

15. Yong VW, Mounjian R, Yong FP, Ruijs TCG, Freedman MS, Cashman $\mathrm{N}$, Antel JP: Gamma interferon promotes proliferation of adult human astrocytes in vitro and reactive gliosis in the adult mouse brain in vivo. Proc Natl Acad Sci USA I991, 88:7016-7020.

16. Raymond C: Diverse approaches to new therapies may hold promise in multiple sclerosis. Diverse approaches to new therapies may hold promise in multiple sclerosis. J Am Med Assoc 1986, 256:685-687.

17. Dumont FJ: Fontolizumab Protein Design Labs. Current Opinion in Investigational Drugs 2005, 6:537-544.

18. Smith KA: Interleukin-2: inception, impact, and implications. Science 1988, 240: I 169-1176.

19. Taniguchi T, Minami Y: The IL-2/IL-2 receptor system: a current overview. Cell 1993, 73:5-8.

20. Minami Y, Kono T, Miyazaki T, Taniguchi T: The IL-2 receptor complex: its structure, function, and targget genes. Annu Rev Immunol 1993, I I:245-267.

21. Smith KS: The quantal theory of how the immune system discriminates between "self and non-self". Med Immunol 2004, 3:3-25.

22. Malek TR, Bayer AL: Tolerance, not immunity, crucially depends on IL-2. Nat Rev Immunol 2004, 4:665-674.

23. Lin J, Li L, Gao Y, Min B, Xu X: IL-2, IFN-gamma, and TNF-alpha mRNA expression in peripheral blood mononuclear cells in patients with multiple sclerosis. Chung Kuo I Hsueh Ko Hsueh Yuan Hsueh Pao 1997, 19:24-28.

24. Kahl KG, Kruse N, Faller H, Weiss H, Rieckmann P: Expression of tumor necrosis factor-alpha and interferon-gamma mRNA in blood cells correlates with depression scores during an acute attack in patients with multiple sclerosis. Psychoneuroendocrinology 2002, 27:671-68I.

25. Debruyne J, Philippe J, Dereuck J, Willems A, Leroux-Roels G: Relapse markers in multiple sclerosis: are in vitro cytokine production changes reflected by circulatory $\mathrm{T}$-cell phenotype alterations? Mult Scler 1998, 4:193-197.

26. Viallard JF, Pellegrin JL, Ranchin V, Schaeverbeke T, Dehais J, LongyBoursier M, Ragnaud JM, Leng B, Moreau JF: Th I (IL-2, interferongamma (IFN-gamma) and Th2 (IL-I O, IL-4) cytokine production by peripheral blood mononuclear cells (PBMC) from patients with systemic lupus erythematosus (SLE). Clin Exp Immunol 1999, I I 5: I89-195.

27. Zhang GX, Navikas V, Link H: Cytokines and the pathogenesis of myasthenia gravis. Muscle Nerve 1997, 20:543-55I.

28. Austin LM, Ozawa M, Kikuchi T, Walters IB, Krueger JG: The majority of epidermal $\mathbf{T}$ cells in Psoriasis vulgaris lesions can produce type I cytokines, interferon-gamma, interleukin-2, and 
tumor necrosis factor-alpha, defining Tcl (cytotoxic T lymphocyte) and THI effector populations: a type I differentiation bias is also measured in circulating blood $T$ cells in psoriatic patients. J Invest Dermatol 1999, I 13:752-759.

29. Fountoulakis M, Juramville JF, Stuber D, Weibel EK, Garotta G: Purification and biochemical characterization of a soluble human interferon gamma receptor expressed in Escherichia coli. J Biol Chem 1990, 265:13268-13275.

30. Basu M, Pace LJ, Pinson MD, Hayes PM, Trotta PP, Russel WS: Purification and partial characterization of a receptor protein for mouse interferon gamma. Proc Natl Acad sci USA 1988, 85:6282-6286.

31. Silva CM, Cidlowski JA: Direct evidence for intra- and intermolecular disulfide bond formation in the human glucocorticoid receptor. Inhibition of DNA binding and identification of a new receptor-associated protein. I Biol Chem 1989, 264:6638-6647.

32. Creighton TE: Disulfide bond formation in proteins. Methods Enzymol 1984, 107:305-329.

33. Sauve K, Nachman M, Spence C, Bailon P, Campell E, Tsien W-H, Kondas JA, Hakimi J, Ju G: Localization in human interleukin 2 of the binding site to the $\alpha$ chain (p55) of the interleukin 2 receptor. Proc Natl Acad Sci USA I99I, 88:4636-4640.

34. Eckenberg R, Xu D, Moreau JL, Bossus M, Mazie JC, Tartar A, Liu XY Alzari PM, Bertoglio J, Theze J: Analysis of human IL-2/IL-2 receptor beta chain interactions: monoclonal antibody $\mathrm{H} 2-8$ and new IL-2 mutants define the critical role of alpha helixA of IL-2. Cytokine 1997, 9:488-498.

35. Eckenberg R, Rose T, Moreau J-L, Weil R, Gesbert F, Dubois S, Tello D, Bossus M, Gras H, Tartar A, Bertoglio G, Chouaïb S, Goldberg M, Jacques $Y$, Alzari PM, Thèze J: The first $\alpha$ helix of interleukin (IL)2 folds as a homotetramer, acts as an agonist of the IL-2 receptor $\beta$ chain, and induces lymphokine-activated killer cells. J Exp Med 2000, 191:529-539.

36. Gardam MA, Keystone EC, Menzies R, Manners S, Skamene E, Long $\mathrm{R}$ : Anti-tumour necrosis factor agents and tuberculosis risk: mechanisms of action and clinical management. Lancet Infect Dis 2003, 3: I $48-155$

37. Mohan N, Edwards ET, Cupps TR, Oliverio PJ, Sanderg G, Crayton H, Richerts JR, siegel JN: Demyelination occurring during antitumor necrosis factor alpha therapy for inflammatory arthritides. Arthritis Rheum 200I, 44:2862-2869.

38. Raghavan $S$, Suri-Payer E, Holmgren J: Antigen-specific in vitro suppression of murine Helicobacter pylori-reactive immunopathological T cells by CD4CD25 regulatory T cells. Scand J Immunol 2004, 60:82-88.

39. Castellanos-Serra L, Hardy E: Detection of biomolecules in electrophoresis gels with salts of imidazole and zinc II: a decade of research. Electrophoresis 200I, 22:864-873.

40. González L), Shimizu T, Satomi Y, Betancourt L, Besada V, Padrón G, Orlando R, Shirasawa T, Shimonishi Y, Takao T: Differentiating alpha- and beta-aspartic acids by electrospray ionization and low-energy tandem mass spectrometry. Rapid Commun Mass Spectrom 2000, 14:2092-2102.

41. Mann M, Wilm M: Error-tolerant identification of peptides in sequence databases by peptide sequence tags. Anal Chem 1994, 66:4390-4399.

42. Vispo NS, Callejo M, Ojalvo AG, Santos A, Chinea G, Gavilondo JV, Araña MJ: Cisplaying human interleukin-2 on the surface of bacteriophage. Immunotechnology 1997, 3:185-193.

43. Gillis $\mathrm{S}$, Ferm MM, Ou W, Smith $\mathrm{KA}$ : T cell growth factor: parameters of production and a quantitative microassay for activity. J Immunol 1978, I 20:2027-2032.

44. Gibson UE, Kramer SM: Enzyme-linked bio-immunoassay for IFN-gamma by HLA-DR induction. J Immunol Methods 1989, 125:105-I|3.
Publish with Biomed Central and every scientist can read your work free of charge

"BioMed Central will be the most significant development for disseminating the results of biomedical research in our lifetime. "

Sir Paul Nurse, Cancer Research UK

Your research papers will be:

- available free of charge to the entire biomedical community

- peer reviewed and published immediately upon acceptance

- cited in PubMed and archived on PubMed Central

- yours - you keep the copyright

Submit your manuscript here:

http://www.biomedcentral.com/info/publishing_adv.asp
BiolMedcentral 